\title{
ОСОБЛИВОСТІ СПРЯМОВАНОСТІ ЯК КОНСТРУКТУ ФУНКЦІОНАЛЬНИХ КОМПОНЕНТІВ КУЛЬТУРИ ПРОФЕСІЙНОГО СПІЛКУВАННЯ ДЕРЖАВНИХ СЛУЖБОВЦІВ ІЗ РІЗНИМ СТАЖЕМ ДІЯЛЬНОСТІ
}

\author{
Ганна Улунова \\ кандидат психологічних наук, доцент кафедри психології, \\ політології та соціокультурних технологій \\ Сумський державний університет \\ 40000, Україна, м. Суми, вул. Римського-Корсакова, 2 \\ uluanna.ua@gmail.com, https://orcid.org/0000-0002-4839-098X
}

\begin{abstract}
Анотація
Статтю присвячено аналізу емпіричного дослідження культури професійного спілкування державних службовців із різним стажем професійної діяльності. Розкрито сутність культури професійного спілкування державних службовців, іiі функціонально-структурні особливості. Проаналізовано результати застосування авторської методики «Культура професійного спілкування державних службовців» за шкалою «спрямованість у професійному спілкуванні». Визначено такі особливості спрямованості як конструкт функціональних компонентів культури професійного спілкування державних службовців. У державних службовців із досвідом професійної діяльності від 0 до 1 року домінує альтероцентристська спрямованість як конструкт перцептивно-аналітичного, конформна спрямованість як конструкт трансляційно-інформаційного та управлінськокоординаційного, діалогічна спрямованість як конструкт особистісно-професійного саморозвитку компонентів культури професійного спілкування державних службовців. У державних службовців із досвідом професійної діяльності від 1 до 10 років домінує діалогічна спрямованість як конструкт перцептивно-аналітичного та трансляційноінформаційного, індиферентна спрямованість як конструкт управлінсько-координаційного та особистісно-професійного саморозвитку компонентів культури професійного спілкування державних службовців. У державних службовців із досвідом професійної діяльності понад 10 років домінує індиферентна спрямованість як конструкт перцептивноаналітичного та трансляційно-інформаційного, маніпулятивна спрямованість як конструкт управлінсько-координаційного та особистісно-професійного саморозвитку компонентів культури професійного спілкування державних службовців.
\end{abstract}

Ключові слова: культура професійного спілкування, державні службовці, спрямованість у професійному спілкуванні, перцептивно-аналітичний компонент, трансляційноінформаційний компонент, управлінсько-координаційний компонент, компонент особистісно-професійного саморозвитку.

\section{Вступ}

Професійна діяльність державних службовців реалізується в складній системі внутрішньоорганізаційних (вертикальних i горизонтальних) i позаорганізаційних комунікацій. Ефективне спілкування з колегами та відвідувачами забезпечує реалізацію 
функціональних обов'язків чиновників, сприяє їх професійній самореалізації та психологічному комфорту на робочому місці.

Ефективність професійної комунікації фахівців у будь-якій сфері професійної діяльності безпосередньо детермінована їх культурою професійного спілкування. Але аналіз наукових робіт, присвячених культурі спілкування/ комунікативній культурі, засвідчив, що рівень розробленості означеної проблеми є неоднаковим для різних сфер професійної діяльності. Наприклад, найбільш дослідженою $є$ культура педагогічного спілкування майбутніх учителів (Варга, 2015), вчителів із досвідом професійної діяльності (M. Cooper, B. Golding \& A. Jin, 2016), керівників навчальних закладів (Зарецька, 2005) та ін. Водночас вивчення культури професійного спілкування державних службовців переважно стосувалося або лише іії одного інваріанта - мовленнєвої культури (Козієвська, 2003), (Михайлець, 2009), або створення педагогічних програм формування в державних службовців культури професійного спілкування (Давидова, 2003; Калашников, 2009) та ін. Це зумовило актуальність вивчення культури професійного спілкування державних службовців як психологічного феномена в його функціональній та структурній єдності.

У попередніх публікаціях ми розкрили, що культура професійного спілкування державних службовців $є$ «інваріантом професійної психологічної культури державних службовців та являє собою комплексне динамічне особистісне утворення державного службовця, яке визначає здатність до ефективного професійного спілкування на державній службі як умови професійної самореалізації при збереженні внутрішнього психологічного комфорту фахівця та потреби до особистісно-професійного вдосконалення в професійному спілкуванні» (Улунова, 2019: 177). У межах діяльнісно-акмеологічного підходу нами було обгрунтовано, що функціональними компонентами культури професійного спілкування державних службовців $\epsilon: 1)$ перцептивно-аналітичний; 2) трансляційно-інформаційний; 3) управлінсько-координаційний; $\quad$ 4) особистіснопрофесійний саморозвиток, а конструктами функціональних компонентів культури професійного спілкування державних службовців $є:$ 1) психологічна готовність державних службовців до професійного спілкування, що утворюється спрямованістю в професійному спілкуванні та психологічною грамотністю в професійному спілкуванні; 2) психологічна компетентність у професійному спілкуванні; 3) акмеологічні інваріанти професіоналізму особистості державного службовця в професійному спілкуванні (Улунова, 2019).

За результатами емпіричного дослідження нами були проаналізовані та висвітлені у публікаціях особливості психологічної компетентності як конструкту функціональних компонентів культури професійного спілкування державних службовців (Улунова, 2018), акмеологічних інваріантів професіоналізму особистості в професійному спілкуванні як конструкту функціональних компонентів культури професійного спілкування державних службовців (Улунова, 2015) тощо. Метою дослідження є визначення особливостей спрямованості в професійному спілкуванні як конструкту функціональних компонентів культури професійного спілкування державних службовців із різним стажем професійної діяльності. Відповідно до визначеної мети вирішувалися такі завдання дослідження: 1) розкриття змісту та структури методики «Культура професійного спілкування державних службовців»; 2) аналіз співвідношення видів спрямованості в професійному спілкуванні державних службовців із різним стажем професійної діяльності; 
3) визначення динаміки спрямованості в професійному спілкуванні державних службовців із різним стажем професійної діяльності.

\section{Методи дослідження}

В основу емпіричного вивчення культури професійного спілкування державних службовців нами було покладено порівняльний метод, що зумовлено специфікою об'єкта дослідження. Цим об’єктом є культура професійного спілкування державних службовців. Але визначати функціонально-структурні особливості культури професійного спілкування державних службовців необхідно шляхом порівняння даних характеристик у чиновників, які мають мінімальний досвід державної служби від 0 до 1 року, мають стаж роботи в державних установах до 10 років, та державних службовців, які працюють у даному статусі понад 10 років.

В якості психодіагностичної методики нами було використано авторську розробку «Діагностика культури професійного спілкування державних службовців» (Улунова, 2019), яка складається 3 підбірки 32 ситуацій професійного спілкування державних службовців із колегами та відвідувачами. Усі ситуації розподілені на 4 блоки відповідно до функціональних компонентів культури професійного спілкування державних службовці. Якщо зміст ситуацій професійного спілкування державних службовців, поданих у методиці, визначається функціональними компонентами культури професійного спілкування державних службовців, то оцінювання досліджуваним кожної ситуації професійного спілкування відбиває конструкти функціональних компонентів культури професійного спілкування державних службовців і здійснюється за трьома напрямками.

Аналіз кожної ситуації професійного спілкування починається 3 психологічної грамотності та психологічної компетентності державних службовців у професійному спілкуванні. Для цього першим запитанням до будь-якої ситуації є таке: «Що, на Вашу думку, необхідно сказати (зробити) в такій ситуації? Що, зазвичай, в такій ситуації говорите (робите) Ви?». До кожного подвійного запитання пропонуються кілька варіантів відповідей.

Для діагностики спрямованості в професійному спілкуванні державних службовців другим запитанням до кожної ситуації є таке: «Чому Ви так вчиняєте?». Спрямованість державних службовців у професійному спілкуванні в методиці оцінюється за видами, виділеними С.Л. Братченко (Братченко, 1997): діалогічна, альтероцентристська, індиферентна, конформна, авторитарна, маніпулятивна. Зазначені види спрямованості в спілкуванні можуть бути розділені на три категорії: конструктивні (діалогічна та альтероцентристська), нейтральні (конформна та індиферентна), неконструктивні (авторитарна та маніпулятивна).

Акмеологічні інваріанти професіоналізму особистості державного службовця в професійному спілкуванні в методиці представлені певними особистісними характеристиками, притаманність яких досліджуваний самооцінює в тій або іншій ситуації професійного спілкування.

Проаналізуємо результати дослідження, отримані за шкалами «Спрямованість у професійному спілкуванні» як конструкт функціональних компонентів культури професійного спілкування державних службовців. 


\section{Результати та дискусії}

Спрямованість у професійному спілкуванні як конструкт функціональних компонентів культури професійного спілкування державних службовців $\epsilon$ системою стійких мотивів, які безпосередньо спонукають суб'єкта до спілкування та грунтуються на його ціннісних орієнтаціях (Улунова, 2019). Особливості спрямованості в професійному спілкуванні як конструкту перцептивно-аналітичного компонента культури професійного спілкування державних службовців визначаються через ранговий аналіз іiі видів у державних службовців із різним професійним досвідом (див. рис. 1.).
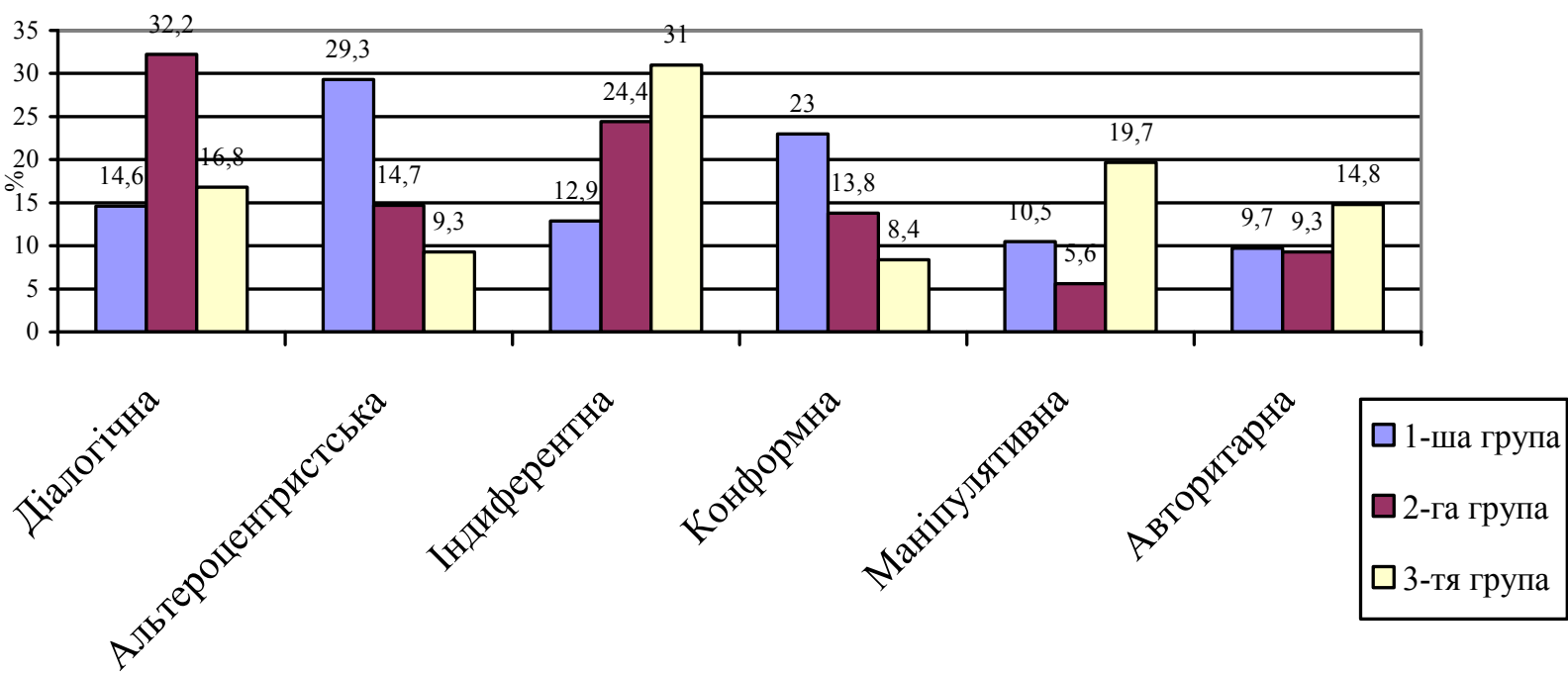

\section{Рис. 1. Види спрямованості в професійному спілкуванні як конструкту перцептивно- аналітичного компонента культури професійного спілкування державних службовців із різним професійним досвідом}

Аналіз результатів, поданих на рис. 1, засвідчує, що державним службовцям, які щойно заступили на державну службу, притаманною $\epsilon$ така поширеність видів спрямованості у професійному спілкуванні: 1-й ранг - альтероцентристська (29,3\%), 2-й ранг - конформна (23,0\%), 3-й ранг - діалогічна (14,6\%), 4-й ранг - індиферентна (12,9\%), 5-й ранг - маніпулятивна (10,5\%), 6-й ранг - авторитарна $(9,7 \%)$. Таким чином, у цієї категорії державних службовців на 1-му та 3-му рангових місцях перебувають найбільш конструктивні види спрямованості в професійному спілкуванні: альтероцентристська та діалогічна, а на останніх - 5-му та 6-му рангових місцях - неконструктивні види спрямованості у професійному спілкуванні: маніпулятивна та авторитарна. Це означає, що більшість вперше призначених на посаду державних службовців при пізнанні іншого суб'єкта спілкування орієнтовані на його цілі, потреби, почуття тощо, готові безкорисливо поступитися власними інтересами.

У державних службовців із досвідом державної служби до 10 років поширеність видів спрямованості у професійному спілкуванні має таку рангову ієрархію: 1-й ранг діалогічна $(32,2 \%)$, 2-й ранг - індиферентна (24,4\%), 3-й ранг - альтероцентристська $(14,7 \%)$, 4-й ранг - конформна $(13,7 \%)$, 5-й ранг - авторитарна $(9,3 \%), 6$-й ранг маніпулятивна (5,6\%). Таким чином, у цієї категорії державних службовців відбуваються зміни домінуючих видів спрямованості у професійному спілкуванні, але, незважаючи на 
це, на 1-му та 3-му рангових місцях знову перебувають найбільш конструктивні види спрямованості у професійному спілкуванні, а найбільш неконструктивні - займають останні рангові місця. Тобто соціальна перцепція державних службовців із досвідом професійної діяльності до 10 років грунтується на орієнтації на рівноправне спілкування, взаємній повазі та довірі, орієнтації на взаєморозуміння, взаємній відкритості та комунікативній співпраці.

Для державних службовців із досвідом професійної діяльності понад 10 років характерним є такий ранговий розподіл видів спрямованості у професійному спілкуванні: 1-й ранг - індиферентна (31,0\%), 2-й ранг - маніпулятивна (19,7\%), 3-й ранг - діалогічна $(16,8 \%), 4$-й ранг - авторитарна (14,8\%), 5-й ранг - альтероцентристська $(9,3 \%), 6$-й ранг конформна $(8,4 \%)$. Таким чином, хоча в цієї категорії державних службовців на 1-му ранговому місці перебуває нейтральна індиферентна спрямованість у професійному спілкуванні, уже на 2-му і 4-му рангових місцях розміщені неконструктивні види спрямованості в професійному спілкуванні: маніпулятивна та авторитарна, а найбільш конструктивні види спрямованості у професійному спілкуванні - альтероцентристська та діалогічна - на 3-му та 5-му рангових місцях. Поява в державних службовців із досвідом професійної діяльності понад 10 років на першому місці індиферентної спрямованості в професійному спілкуванні свідчить про їх орієнтацію на рішення суто ділових питань, на ділову комунікацію та предметну взаємодію.

Таким чином, перцептивно-аналітичний компонент культури професійного спілкування державних службовців із різним професійним досвідом характеризується негативною динамікою в процесі професійної діяльності державних службовців спрямованості в професійному спілкуванні.

Ранговий аналіз видів спрямованості в професійному спілкуванні державних службовців як конструкту трансляційно-інформаційного компонента культури професійного спілкування державних службовців із різним професійним досвідом дозволяє визначити такі особливості (див. рис. 2.).

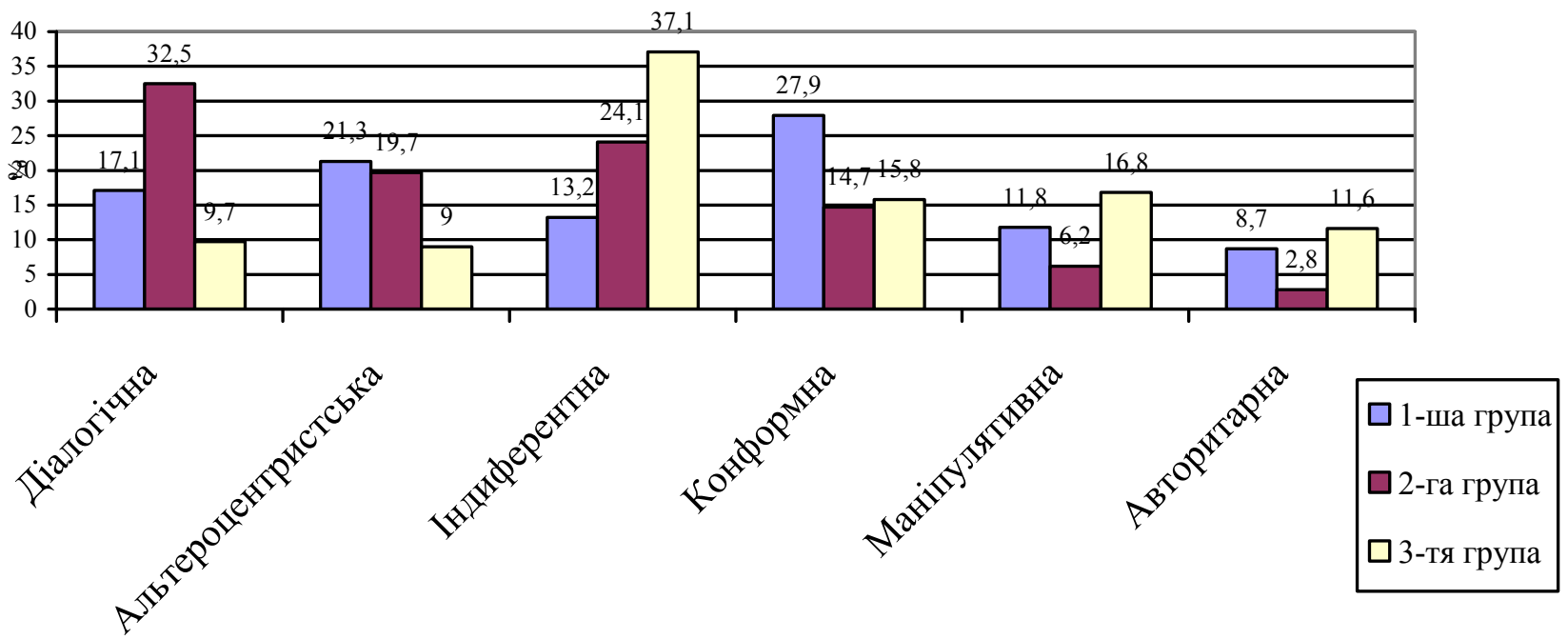

Рис. 2. Види спрямованості в професійному спілкуванні як конструкту трансляційноінформаційного компонента культури професійного спілкування державних службовців із різним професійним досвідом 
Аналіз результатів, поданих на рис. 2, засвідчує, що державним службовцям, які щойно заступили на державну службу, притаманною $\epsilon$ така поширеність видів спрямованості в професійному спілкуванні: 1-й ранг - конформна (27,9\%), 2-й ранг альтероцентристська $(21,3 \%)$, 3-й ранг - діалогічна $(17,1 \%)$, 4-й ранг - індиферентна $(13,2 \%), 5$-й ранг - маніпулятивна $(11,8 \%), 6$-й ранг - авторитарна $(8,7 \%)$. Таким чином, незважаючи на те, що у цієї категорії державних службовців на 1-му ранговому місці перебуває нейтральна конформна спрямованість в професійному спілкуванні, на 2-му та 3-му рангових місцях перебувають найбільш конструктивні види спрямованості в професійному спілкуванні: альтероцентристська та діалогічна, а на останніх - 5-му і 6-му рангових місцях - неконструктивні види спрямованості в професійному спілкуванні: маніпулятивна та авторитарна. Розташування у вперше призначених на посаду державних службовців на першому місці конформної спрямованості свідчить про те, що при обміні інформацією з іншими суб'єктами спілкування чиновники готові відмовитися від рівноправності в спілкуванні на користь партнера, орієнтовані на підпорядкування силі авторитету, на «об’єктну» позицію для себе, на некритичну згоду й уникнення протидії;

У державних службовців із досвідом державної служби до 10 років поширеність видів спрямованості у професійному спілкуванні має таку рангову ієрархію: 1-й ранг діалогічна $(32,5 \%)$, 2-й ранг - індиферентна $(24,1 \%)$, 3-й ранг - альтероцентристська

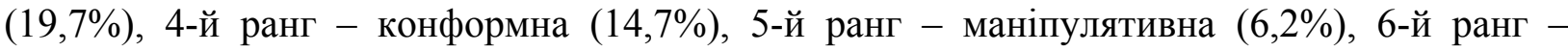
авторитарна (2,8\%). Таким чином, у цієї категорії державних службовців на 1-му та 3-му рангових місцях перебувають конструктивні діалогічна та альтероцетристська види спрямованості у професійному спілкуванні, на 2-му та 4-му рангових місцях - нейтральні види спрямованості у професійному спілкуванні - індиферентна та конформна, а найбільш неконструктивні види спрямованості у професійному спілкуванні: маніпулятивна та авторитарна - на останніх рангових місцях. Це означає, що процес комунікації в державних службовців із досвідом професійної діяльності понад 10 років відбувається в умовах рівноправності позицій у спілкуванні, аргументуванні власної точки зору та готовності почути думку співрозмовника. Зазначене співвідношення видів спрямованості в професійному спілкуванні докорінно змінюється в державних службовців зі стажем діяльності понад 10 років.

Так, для державних службовців із досвідом професійної діяльності понад 10 років характерним $є$ такий ранговий розподіл видів спрямованості в професійному спілкуванні: 1-й ранг - індиферентна $(37,1 \%), 2$-й ранг - маніпулятивна $(16,8 \%), 3$-й ранг - конформна $(15,8 \%)$, 4-й ранг - авторитарна $(11,6 \%), 5$-й ранг - діалогічна $(9,7 \%)$, 6-й ранг альтероцентристська (9,0\%). Таким чином, хоча в цієї категорії державних службовців на 1-му і 3-му рангових місцях перебувають нейтральні індиферентна та конформна види спрямованості у професійному спілкуванні, вже на 2-му і 4-му рангових місцях розташовані неконструктивні види спрямованості у професійному спілкуванні: маніпулятивна та авторитарна, а на останніх - 5-му і 6-му рангових місцях - найбільш конструктивні види спрямованості у професійному спілкуванні: альтероцентристська та діалогічна. Домінування в державних службовців із досвідом професійної діяльності понад 10 років маніпулятивної спрямованості доводить, що при передачі та декодуванні інформації чиновники орієнтовані на використання партнера у власних цілях для одержання різного роду вигоди. 
Таким чином, трансляційно-інформаційний компонент культури професійного спілкування державних службовців із різним професійним досвідом характеризується позитивно-негативною динамікою в процесі професійної діяльності державних службовців спрямованості в професійному спілкуванні.

Ранговий аналіз видів спрямованості в професійному спілкуванні як конструкту управлінсько-координаиійного компонента культури професійного спілкування державних службовців із різним професійним досвідом дозволяє визначити такі особливості (див. рис. 3).
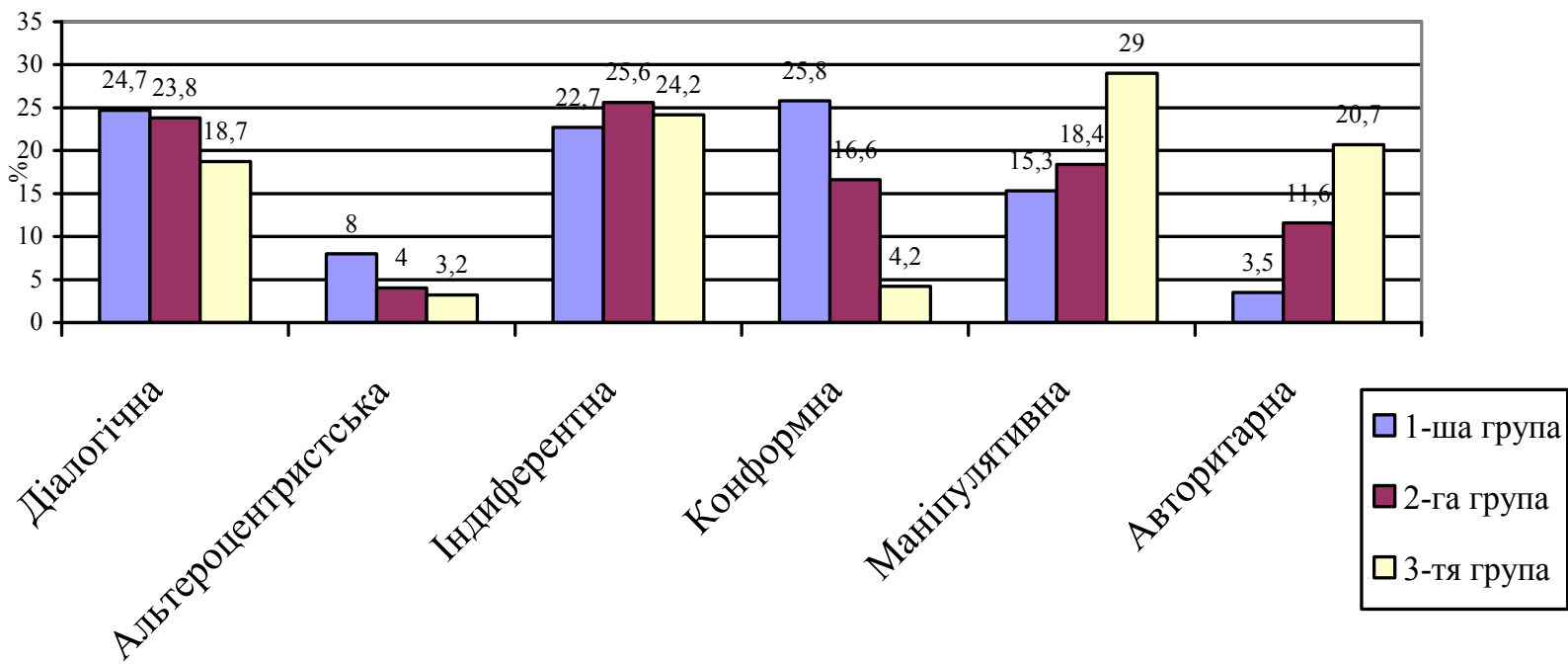

\section{Рис. 3. Види спрямованості в професійному спілкуванні як конструкту управлінсько- координаційного компонента культури професійного спілкування державних службовців із різним професійним досвідом}

Аналіз результатів, поданих на рис. 3, засвідчує, що державним службовцям, які щойно заступили на державну службу, притаманною $\epsilon$ така поширеність видів спрямованості у професійному спілкуванні: 1-й ранг - конформна (25,8\%), 2-й ранг діалогічна $(24,7 \%), 3$-й ранг - індиферентна $(22,7 \%)$, 4-й ранг - маніпулятивна $(15,3 \%), 5$-й ранг - альтероцентристська (8,0\%), 6-й ранг - авторитарна (3,5\%). Отже, незважаючи на те, що в цієї категорії державних службовців на 1-му та 3-му рангових місцях перебувають нейтральні конформна та індиферентна спрямованість у професійному спілкуванні, на 2му ранговому місці - найбільш конструктивна діалогічна спрямованість у професійному спілкуванні. Це означає, що більшість вперше призначених на посаду державних службовців при керуванні процесом спілкування орієнтовані насамперед на збереження гарних стосунків з іншими суб'єктами спілкування, навіть на шкоду власним цілям та інтересам.

У державних службовців із досвідом державної служби до 10 років поширеність видів спрямованості у професійному спілкуванні має таку рангову ієрархію: 1-й ранг індиферентна (25,6\%), 2-й ранг - діалогічна (23,8\%), 3-й ранг - маніпулятивна $(18,4 \%), 4$-й ранг - конформна (16,6\%), 5-й ранг - авторитарна (11,6\%), 6-й ранг - альтероцентристська (4,0\%). Отож, у цієї категорії державних службовців на 1-му ранговому місці перебуває нейтральна індиферентна спрямованість у професійному спілкуванні, на 2-му ранговому місці - конструктивна діалогічна спрямованість у професійному спілкуванні, але 3-тє 
рангове місце займає неконструктивна маніпулятивна спрямованість у професійному спілкуванні. Наявність у державних службовців із досвідом професійної діяльності до 10 років на першому місці індиферентної спрямованості свідчить, що суб'єктність чиновників у професійному спілкуванні підпорядкована їх діловим інтересам і цілям професійної діяльності.

Для державних службовців із досвідом професійної діяльності понад 10 років характерним $\epsilon$ такий ранговий розподіл видів спрямованості в професійному спілкуванні: 1-й ранг - маніпулятивна (29,0\%), 2-й ранг - індиферентна (24,2\%), 3-й ранг - авторитарна $(20,7 \%), 4$-й ранг - діалогічна $(18,7 \%), 5$-й ранг - конформна $(4,2 \%)$, 6-й ранг альтероцентристська (3,2\%). Таким чином, у цієї категорії державних службовців на 1-му та 3-му рангових місцях перебувають неконструктивні види спрямованості в професійному спілкуванні: маніпулятивна та авторитарна, на 2-му ранговому місці нейтральна індиферентна спрямованість у професійному спілкуванні, конструктивні ж види спрямованості в професійному спілкуванні: альтероцентристська та діалогічна займають лише 4-те та 6-те рангові місця. Тобто, державні службовці із досвідом професійної діяльності понад 10 років, керуючи процесом спілкування, ставляться до партнера як до засобу, об'єкта своїх маніпуляцій. Отже, управлінсько-координаційний компонент культури професійного спілкування державних службовців із різним професійним досвідом характеризується негативною динамікою в процесі професійної діяльності державних службовців спрямованості в професійному спілкуванні.

Ранговий аналіз видів спрямованості у професійному спілкуванні як конструкту особистісно-професійного саморозвитку як компонента культури професійного спілкування державних службовців із різним професійним досвідом дозволяє визначити такі особливості (див. рис. 4.).
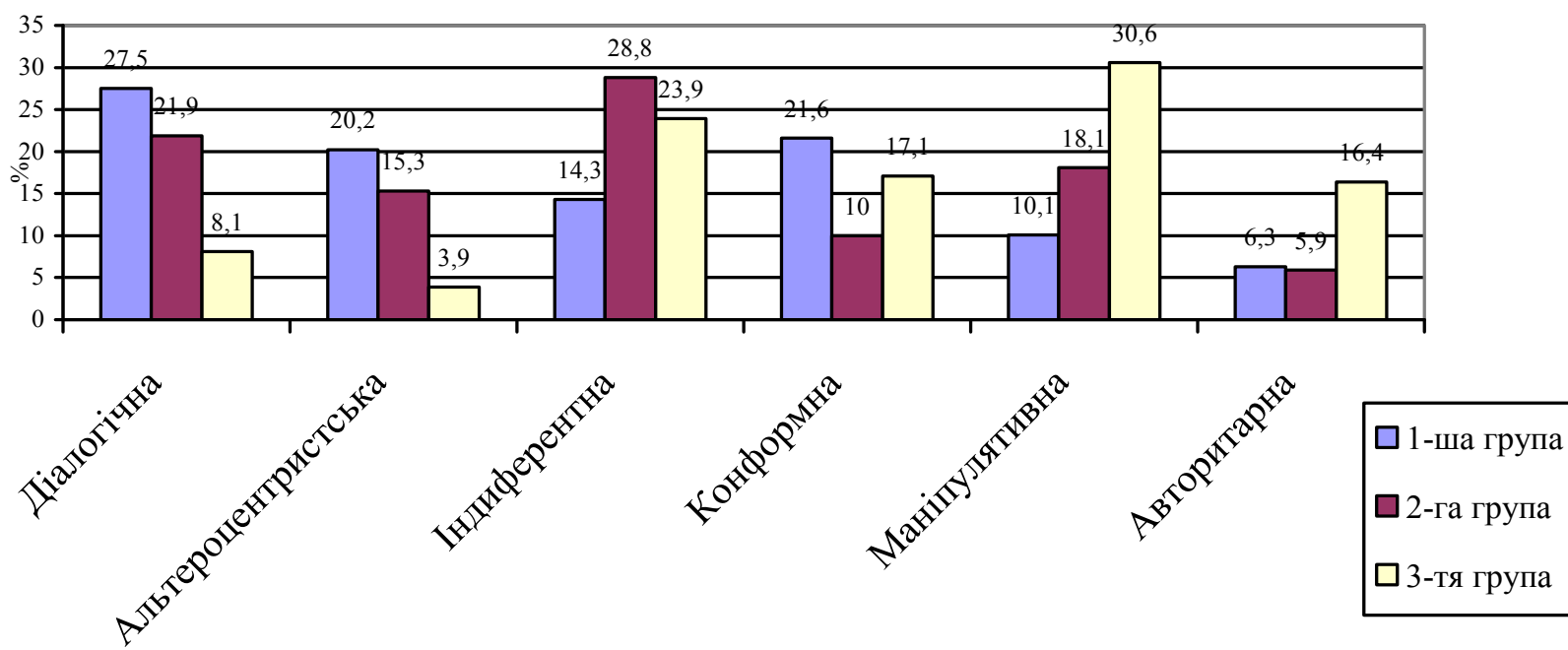

Рис. 4. Види спрямованості в професійному спілкуванні як конструкту особистіснопрофесійного саморозвитку як компонента культури професійного спілкування державних службовців із різним професійним досвідом

Аналіз результатів, поданих на рис. 4, засвідчує таке. Для вперше призначених на посаду державних службовців притаманною $є$ така поширеність видів спрямованості у професійному спілкуванні: 1-й ранг - діалогічна (27,5\%), 2-й ранг - конформна (21,6\%), 3- 
й ранг - альтероцентристська (20,2\%), 4-й ранг - індиферентна $(14,3 \%), 5$-й ранг маніпулятивна (10,1\%), 6-й ранг - авторитарна (6,3\%). Отож, у цієї категорії державних службовців на 1-му та 3-му рангових місцях перебувають найбільш конструктивні види спрямованості у професійному спілкуванні: діалогічна та альтероцентристська, а на 2-му і 4-му рангових місцях - нейтральні: конформна та індиферентна спрямованості у професійному спілкуванні. Це означає, що більшість вперше призначених на посаду державних службовців прагнуть до взаємного самовираження 3 партнером по спілкуванню та саморозвитку в комунікативній сфері.

У державних службовців із досвідом державної служби до 10 років поширеність видів спрямованості у професійному спілкуванні має таку рангову ієрархію: 1-й ранг індиферентна (28,8\%), 2-й ранг - діалогічна (21,9\%), 3-й ранг - маніпулятивна $(18,1 \%), 4$-й ранг - альтероцентристська $(15,3 \%), 5$-й ранг - конформна (10,0\%), 6-й ранг - авторитарна (5,9\%). Отже, у цієї категорії державних службовців на 1-му ранговому місці перебуває нейтральна індиферентна спрямованість у професійному спілкуванні, на 2-му ранговому місці - конструктивна діалогічна спрямованість у професійному спілкуванні, а 3-тє рангове місце займає неконструктивна маніпулятивна спрямованість у професійному спілкуванні. Поява в державних службовців із досвідом професійної діяльності до 10 років на першому місці індиферентної спрямованості свідчить, що їх готовність розвиватися в комунікативній сфері продиктована суто діловими потребами, розумінням необхідності підвищувати власну професійну ефективність.

Для державних службовців із досвідом професійної діяльності понад 10 років характерним $\epsilon$ наступний ранговий розподіл видів спрямованості у професійному спілкуванні: 1-й ранг - маніпулятивна (30,6\%), 2-й ранг - індиферентна (23,9\%), 3-й ранг конформна $(17,1 \%), 4$-й ранг - авторитарна $(16,4 \%), 5$-й ранг - діалогічна $(8,1 \%), 6$-й ранг - альтероцентристська (3,9\%). Таким чином, у цієї категорії державних службовців на 1му ранговому місці перебуває неконструктивна маніпулятивна спрямованість у професійному спілкуванні, на 2-му ранговому місці - нейтральна індиферентна спрямованість у професійному спілкуванні, конструктивні ж види спрямованості у професійному спілкуванні: альтероцентристська та діалогічна займають лише 5-те та 6-те рангові місця. Отже, готовність державних службовців із досвідом професійної діяльності понад 10 років до саморозвитку пов'язана з бажанням безконфліктно використовувати інших суб'єктів спілкування для реалізації виключно власних потреб.

Таким чином, особистісно-професійний саморозвиток як компонент культури професійного спілкування державних службовців із різним професійним досвідом характеризується негативною динамікою в процесі професійної діяльності державних службовців спрямованості в професійному спілкуванні.

\section{Висновки}

Перцептивно-аналітичний компонент культури професійного спілкування в державних службовців із досвідом професійної діяльності від 0 до 1 року характеризується домінуванням альтероцентристської спрямованості, в державних службовців із досвідом професійної діяльності до 10 років - діалогічної спрямованості, а в державних службовців із досвідом професійної діяльності понад 10 років - індиферентної спрямованості. Трансляційно-інформаційний компонент культури професійного 
спілкування в державних службовців із досвідом професійної діяльності від 0 до 1 року характеризується домінуванням конформної спрямованості, в державних службовців із досвідом професійної діяльності до 10 років - діалогічної спрямованості, а в державних службовців із досвідом професійної діяльності понад 10 років - індиферентної спрямованості. Управлінсько-координаційний компонент культури професійного спілкування в державних службовців із досвідом професійної діяльності від 0 до 1 року характеризується домінуванням конформної спрямованості, в державних службовців із досвідом професійної діяльності до 10 років - індиферентної спрямованості, а в державних службовців із досвідом професійної діяльності понад 10 років маніпулятивної спрямованості. Особистісно-професійний саморозвиток як компонент культури професійного спілкування в державних службовців із досвідом професійної діяльності від 0 до 1 року характеризується домінуванням діалогічної спрямованості, в державних службовців із досвідом професійної діяльності до 10 років - індиферентної спрямованості, а в державних службовців із досвідом професійної діяльності понад 10 років - маніпулятивної спрямованості.

Перспективу подальших досліджень ми вбачаємо у врахуванні отриманих результатів дослідження в розробці програм розвитку культури професійного спілкування у державних службовців із різним досвідом професійної діяльності.

\section{Література}

1. Братченко, С.Л. (1997). Диагностика личностно-развивающего потенииала : методическое пособие для школьных психологов. Псков : ПОИПКРО.

2. Варга, Л.І. (2015) Особливості формування комунікативної культури майбутніх учителів засобами інтерактивних технологій. Наука і освіта, 9, 15-19.

3. Давыдова, О.А. (2003). Формирование культуры делового общения у будущих государственных служащих. (Дисс. канд. пед. наук). Волгоград.

4. Зарецька, I.I. (2005). Комунікативна культура як компонент педагогічної культури. Директор школи. Україна, 3-5, 149-157; 6-7; 90-101.

5. Калашников, М.M. (2009). Формирование культуры делового общения государственных служащих в системе непрерывного образования. (Автореф. дис. канд. пед. наук). Орел.

6. Улунова, Г.С. (2015). Ідеальний та реальний профілі комунікативно-організаторських якостей державних службовців. Nowoczesna edukacja: filozofia, innowacja, doświadczenie, 2, 82-86. Łódź : Wydawnictwo Naukowe Wyższej Szkoły Informatyki i Umiejętności.

7. Улунова, Г.Є. (2019). Культура професійного спілкування державних службовців: сутність, функиіонально-структурні особливості, психодіагностика. (Монографія). Суми : СумДУ.

8. Улунова, Г.С. (2018). Особливості психологічної підготовленості як структурного компоненту управлінсько-координаційного аспекту культури професійного спілкування державних службовців. Науковий часопис Національного педагогічного університету імені М.П. Драгоманова. Серія 12 : Психологічні науки, 7 (52), 236-243. 
9. Cooper, M., Golding, B., Jin, A. (2016). Cross-Cultural Communication in Teacher Education. Australian Journal of Teacher Education, 41, 6, 20-34. Retrieved from https://files.eric.ed.gov/fulltext/EJ1112384.pdf

\section{References}

1. Bratchenko, S.L. (1997). Diagnostika lichnostno-razvivajushhego potenciala : metodicheskoe posobie dlja shkol'nyh psihologov. [Diagnostics of personal development potential: a methodological manual for school psychologists]. Pskov : POIPKRO [in Russian].

2. Varha, L.I. (2015) Osoblyvosti formuvannia komunikatyvnoi kultury maibutnikh uchyteliv zasobamy interaktyvnykh tekhnolohii. [Features of formation of communicative culture of future teachers by means of interactive technologies]. Nauka i osvita - Science and education. 9, 15-19 [in Ukrainian].

3. Davydova, O.A. (2003). Formirovanie kul'tury delovogo obshhenija u budushhih gosudarstvennyh sluzhashhih. [The formation of a culture of business communication of future public servants]. Candidate thesis. Volgograd [in Russian].

4. Zaretska, I.I. (2005). Komunikatyvna kultura yak komponent pedahohichnoi kultury [Communicative culture as a component of pedagogical culture]. Dyrektor shkoly. Ukraina - School Director. Ukraine, 3-5, 149-157; 6-7, 90-101 [in Ukrainian].

5. Kalashnikov, M.M. (2009). Formirovanie kul'tury delovogo obshhenija gosudarstvennyh sluzhashhih v sisteme nepreryvnogo obrazovanija [The formation of a culture of business communication of civil servants in the continuing education system]. Extendid abstract of Candidate 's thesis. Orel [in Russian].

6. Ulunova, H.Ye. (2015). Idealnyi ta realnyi profili komunikatyvno-orhanizatorskykh yakostei derzhavnykh sluzhbovtsiv. [Ideal and real profiles of communication and organizational skills of civil servants]. Nowoczesna edukacja: filozofia, innowacja, doświadczenie Modern education: philosophy, innovation, experience, 2, 82-86. Łódź : Wydawnictwo Naukowe Wyższej Szkoły Informatyki i Umiejętności [in Poland].

7. Ulunova, H.Ye. (2019). Kultura profesiinoho spilkuvannia derzhavnykh sluzhbovtsiv: sutnist, funktsionalno-strukturni osoblyvosti, psykhodiahnostyka [Culture of professional communication of civil servants: content, functional and structural features, psychodiagnosis]. Sumy : SumDU [in Ukrainian].

8. Ulunova, H.Ye. (2018). Osoblyvosti psykholohichnoi pidhotovlenosti yak strukturnoho komponentu upravlinsko-koordynatsiinoho aspektu kultury profesiinoho spilkuvannia derzhavnykh sluzhbovtsiv [The peculiarities of psychological preparedness as a structural component of the managerial-coordination aspect of the culture of professional communication among civil servants]. Naukovyi chasopys Natsionalnoho pedahohichnoho universytetu imeni M.P. Drahomanova. Seriia 12 : Psykholohichni nauky - Scientific journal of M.P. Dragomanov National Pedagogical University. Series 12: Psychological Sciences, 7 (52), 236-243. [in Ukrainian].

9. Cooper, M., Golding, B., Jin, A. (2016). Cross-Cultural Communication in Teacher Education, 41, 6, 20-34. Retrieved from https:/files.eric.ed.gov/fulltext/EJ1112384.pdf [in Australia]. 


\title{
PECULIARITIES OF ORIENTATION AS A CONSTRUCT OF FUNCTIONAL COMPONENTS OF PROFESSIONAL COMMUNICATION CULTURE OF CIVIL SERVANTS WITH DIFFERENT EXPERIENCE Hanna Ulunova \\ PhD in Psychology, Associate Professor, Associate Professor of the Department of Psychology, Political Science and Sociocultural Technologies \\ Sumy State University \\ 2, Rymskyi-Korsakov Str., Sumy, Ukraine, 40000 \\ uluanna.ua@gmail.com, https://orcid.org/0000-0002-4839-098X
}

\begin{abstract}
The article is devoted to the analysis of the empirical study of professional communication culture of civil servants with different professional experience. The essences of civil servants' professional communication culture, its functional and structural features have been in the focus of the research. The results of applying the author's methodology «Civil Servants' Professional Communication Culture» have been analyzed according to the scale of «orientation in professional communication». Such peculiarities of orientation as a construct of functional components of civil servants' professional communication culture have been defined. Civil servants with the professional experience to 1 year tend to display the dominant alterocentric orientation as a construct of perceptive-analytical, the conformal orientation as a construct of translational-informational and managerial-coordinative, the dialogical orientation as a construct of personal-professional self-development of civil servants' professional communication culture components. Civil servants with the professional experience from 1 year to 10 years are inclined to demonstrate the dominant dialogical orientation as a construct of perceptual-analytical and translational-informational, the indifferent orientation as a construct of managerial-coordinative and personal-professional self-development of civil servants' professional communication culture components. Civil servants with more than 10 years of professional experience have proven to display the dominant indifferent orientation as a construct of perceptive-analytical and translational-informational, the manipulative orientation as a construct of managerialcoordinative and personal-professional self-development of civil servants' professional communication culture components.
\end{abstract}

Keywords: professional communication culture, civil servants, professional communication orientation, perceptive-analytical component, translational-informational component, managerial-coordinative component, component of personal-professional self-development. 